\title{
Can Forest Management Units Improve Community Access to the Forest?
}

Golar Golar ${ }^{*}$, Hasriani Muis ${ }^{1}$, Sudirman Dg Massiri ${ }^{1}$, Abdul Rahman ${ }^{1}$, Arman Maiwa ${ }^{1}$, Fardhal Pratama ${ }^{2}$, Rhamdhani Fitrah Baharuddin ${ }^{1}$, Wahyu Syahputra Simorangkir ${ }^{1}$

${ }^{1}$ Forestry Faculty of Tadulako University, Central Sulawesi, Palu 94119, Indonesia

${ }^{2}$ Agriculture Faculty of Tadulako University, Central Sulawesi, Palu 94119, Indonesia

Corresponding Author Email: golar.tadulako@gmail.com

https://doi.org/10.18280/ijdne.160511

Received: 7 September 2021

Accepted: 30 September 2021

\section{Keywords:}

deforestation, forest management unit, forest

access, forest partnership

\begin{abstract}
This paper examines the Forest Management Unit's (FMU) role in enhancing access to forest area utilization, especially in production and protected community-based forests, to suppress the rate of deforestation. We research five FMU in central Sulawesi. The analysis method is qualitative based on emic information from FMU, community, academic, local government, and direct field observations. This paper explains that public access in forest resource utilization is a deciding factor in helping the community face the impact of economic crises. To make it happen, the primary role of FMU is necessary. FMU Should be increasing public access to the state-owned forest by optimizing the facilitating functions. Providing investment opportunities for forest management based on the community in partnership schemes can realize a broad impact and national issues on empowering forest communities. FMU can also prioritize the partnership cooperation programs by implementing social forestry programs, instantly absorbing significant community participation.
\end{abstract}

\section{INTRODUCTION}

Land degradation and deforestation are the main factors increasing environmental damage [1-3]. It is caused that most people still rely on forests [4]. They utilize forest resources to fulfill daily needs and significant income $[5,6]$.

In Indonesia, the communities can utilize the state forest through licensing, requiring strict stages and utilization procedures [7]. The complicated permitting assessment was an inhibitory factor to access forest resources $[8,9]$. A high need's insistence can't postpone encouraging them to do illegal logging [10]. In some areas, especially those bordering on forest areas, the community finds several illicit timber violations.

On the other hand, the empowerment programs for communities near and in forest areas are social forestry programs, consist of five models: community forests, village forests, people's crop forests, and partnerships. Other schemes that do not go well are affected by the pandemic Covid-19 [11] and the community resistance [12]. This situation is found mainly in Forest Management Unit (FMU) areas in productions and or protected forest functions. Several studies report that it caused the weak role of the FMU as the institution managing forest at the site level $[13,14]$. It should be the FMU whose control facilitates empowering programs [15].

The impact is that people are looking for other alternatives to earn income [16]. FMU is expected to prevent land conflicts and forest use in managed areas due to its facilitation function. Through the facilitation, the operation can be attempted to be carried out community empowerment schemes by utilizing the potential of natural resources contained in the forest area through the provision of access to the utilization of forest timber products, non-timber, and environmental services.
However, the FMU is often characterized by issues of tenurial conflict involving the community. It is related to government agencies and between communities and forest concession holders (forest use permits and plantation permits) and conflicts between community groups.

Tenurial problems experienced by FMU, especially in central Sulawesi, are triggered by land tenure claims, land occupancy "inability" problems by the community, and exforest concession areas that impact open access areas. It shows the high dependence of the community on forest land and less concern for the district to the rules of utilization in state-owned forests.

This situation boils down to tenurial conflict in most areas of FMU. One of the relatively easy to earn revenue quickly is cutting trees and utilizing forest land. They know that these activities are illegal and have a significant risk [17]. Higher demand for timber on the communities' needs motivates them $[18,19]$. If not resolved immediately, this condition will profoundly impact the damage to increased forest resources [20].

As a forest managing, FMU will be directly involved in "facilitating" the resolution of forest tenure conflict problems. The issue of tenurial conflict in the FMU region will be a factor that hinders effective FMU management, especially in the implementation of facilitation processes for the utilization of land and forest products [20, 21]. Therefore, FMU needs to target land-use efficiency, policy, and national demand related to sustainable forest management.

Some research reports that common illness potentially poses a tenurial conflict in the forest community $[6,15]$, affecting forest sustainability [22]. Therefore, it requires the humanist approach to meet the community's needs, low-risk forest damage, and help overcome the social crisis. 
This paper examines: What factors cause FMU institutions to weaken against its forest management? What are the potential conflicts in the forest areas of the FMU? What is the role of FMU in improving access to forest utilization, especially in production and or protected forest? Both conceptual and practical are presented alternative schemes of utilizing FMU-based forest areas, accelerating the empowerment program, and increasing public income with relatively low-risk forest damage.

\section{MATERIAL \& METHOD}

This research was conducted in 5 (five) areas of FMU, from a total of 13 FMU in Central Sulawesi - Indonesia, including Dampelas Tinombo, Toili Baturube, Kulawi, Pogogul, and Sintuwu Maroso (Figure 1). Location determination is done purposive sampling, with the primary consideration: The area of FMU with a management plan; Identified potential tenurial conflicts in its governance areas. The important one in the community and the local government is the permit and opportunity to interact with the research activities.

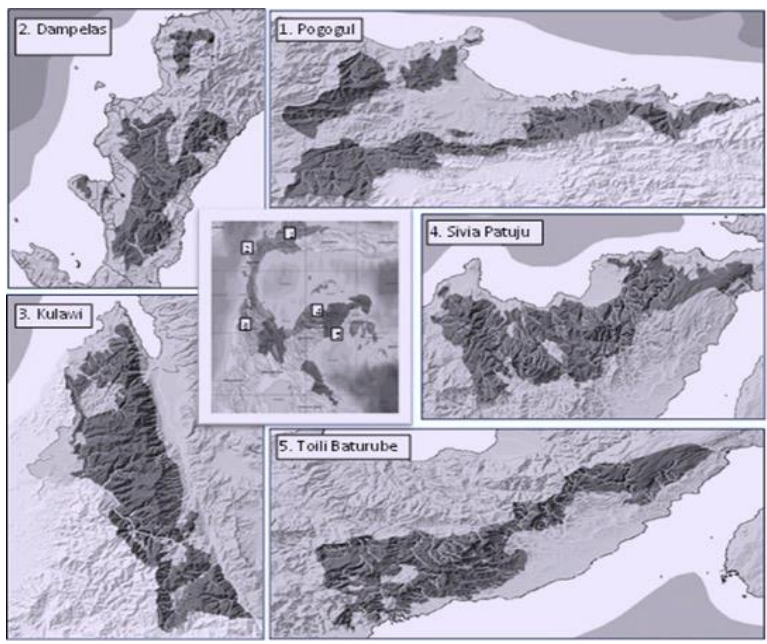

Figure 1. Research site locations of FMU area in central Sulawesi

While the research was conducted, the Indonesian government was implementing rules to limit the mobility of its citizens to prevent the impact of COVID-19 disease, including restrictions on research activities in the field. Researchers are required to implement prevention - procedures and task force permits of the COVID-19. Therefore, the data was collected adapted using many ways: The Google form, WhatsApp, Zoom meeting, Email, and in-depth interviews online and offline (limited discussion). Also, we use the survey method to direct observation of the forest resource utilization by the community in owned-state forests.

Questionnaires form a Google form distributed to the head of the FMU, several group leaders, and members representatives in the FMU target village filled with potential conflicts and access to forest areas in the FMU governance area. To make it easy, we use simple questions but focus on the main issue. Data on the chronological was conducted through direct communication using a mobile phone and WhatsApp video conference tools to the head of Forestry Department of Central Sulawesi Province, 5 (five) head of the FMU, and academics who studied the institutional research on FMU. The types of data collected can see in Table 1.

Table 1. Types and sources of data collected

\begin{tabular}{|c|c|c|c|}
\hline No & Type of Data & Source & $\begin{array}{c}\text { Data Collection } \\
\text { Methods }\end{array}$ \\
\hline 1 & $\begin{array}{c}\text { Chronological } \\
\text { weakening function } \\
\text { and role of FMU }\end{array}$ & $\begin{array}{l}\text { 1. Head of } \\
\text { Forestry } \\
\text { Department } \\
\text { 2. Head of the } \\
\text { FMU } \\
\text { 3. Academics } \\
\text { 4. forestry } \\
\text { extension } \\
\text { officer }\end{array}$ & $\begin{array}{c}\text { 1. Mobile } \\
\text { phone; } 2 . \text { Email; } \\
\text { 3. Zoom } \\
\text { meeting; } 4 \text {. } \\
\text { Limited meeting }\end{array}$ \\
\hline 2 & $\begin{array}{l}\text { Potential tenurial } \\
\text { conflicts in the } \\
\text { region of the FMU }\end{array}$ & $\begin{array}{l}\text { 1. Head of the } \\
\text { FMU } \\
\text { 2. Head of } \\
\text { farmer Group } \\
\text { 3. forestry } \\
\text { extension } \\
\text { officer } \\
\text { 4. Field } \\
\text { observations }\end{array}$ & $\begin{array}{l}\text { 1. Mobile } \\
\text { phone; } 2 \text {. } \\
\text { Google phone; } \\
\text { 3. Zoom } \\
\text { meeting. }\end{array}$ \\
\hline 3 & $\begin{array}{l}\text { Empowerment } \\
\text { Program in on- } \\
\text { going FMU area- } \\
\text { planned, and stalled }\end{array}$ & $\begin{array}{l}\text { 1. Head of the } \\
\text { FMU } \\
\text { 2. Head of } \\
\text { farmer Group } \\
\text { 3. forestry } \\
\text { extension } \\
\text { officer } \\
\text { 4. Realization } \\
\text { Report of FMU } \\
\text { programs }\end{array}$ & $\begin{array}{l}\text { 1. Mobile } \\
\text { phone; } 2 \text {. } \\
\text { Google form; } 3 \text {. } \\
\text { Zoom meeting; } \\
\text { 4. WhatsApp }\end{array}$ \\
\hline
\end{tabular}

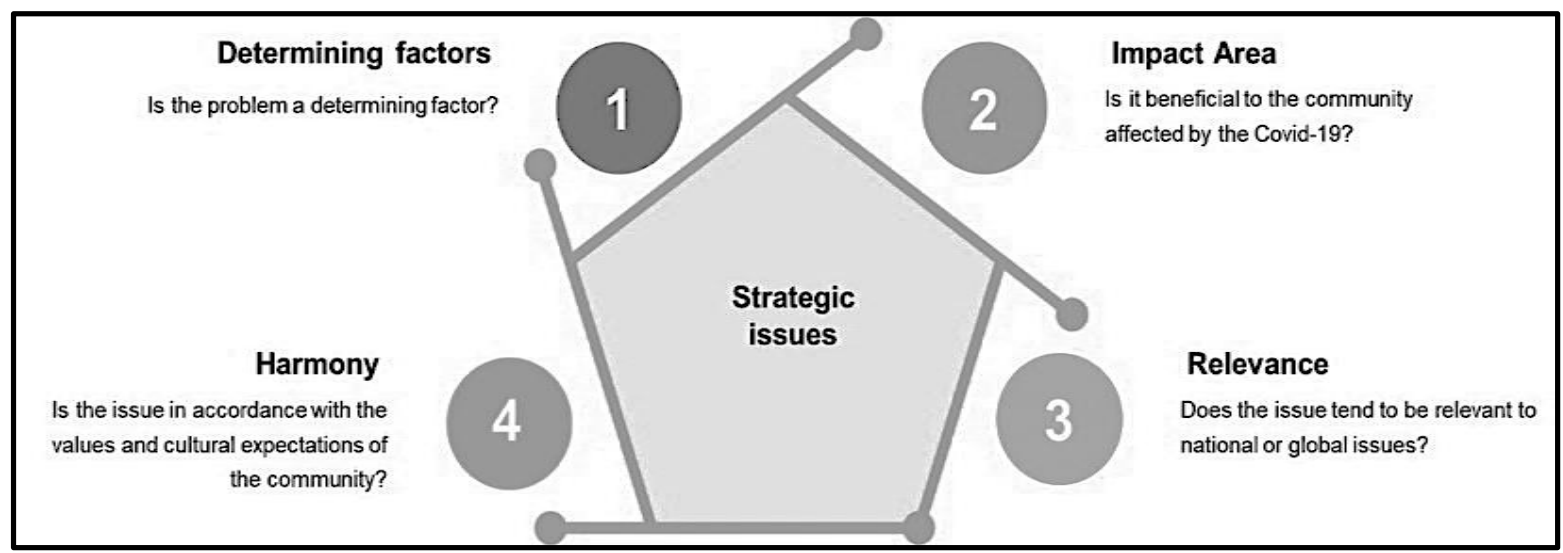

Figure 2. Main parameters determining the strategic problem 
Research data were analyzed using policy analysis. Beginning with an investigation of various issues or related issues to forest management carried out by the FMU, the potential for conflicts in each of the FMU during the Covid-19 period. Next, discussing social problems that become the focus analysis, based on four main parameters: determining factors, the extent of change produced, relevance to national issues, and harmony with social norms [23]. A strategic problem is determined to prepare a solution for handling it (Figure 2).

Utilization is analyzed based on the empowerment activity that the current FMU is implementing-conducted identification and analysis of the program orientation and empowerment objectives. A report known as FMU contributes to providing access to forest resources in the region to the community.

\section{RESULTS \& DISCUSSIONS}

\subsection{FMU dynamics in central Sulawesi}

The Ministry of Forestry has established 21 FMU areas in central Sulawesi in the year 2010. However, the new FMU development commenced in 2011. The central government facilitated three FMU models: Dampelas Tinombo, Sivia Patuju, and Toili Baturube. The central government also promotes the development of office facilities and operational cars for the FMU. However, the relevant FMU does not get the central government's budget allocation, which must be addressed through provincial and district funding. The situation resulted in the operationalization of the FMU experiencing financing barriers. Because of the limit, the FMU implementation is affected.

The situation is felt evenly on the 21 FMU that have formed at the time. Only a few FMU can adapt and remain operational in the middle of the limited budgeting. Some research reported that the restricted problem of regional funding support to the FMU triggered the operationalization so that its functions and duties could not run correctly [24].

In the year 2014, the government issued No. 23, on the authority of local government. The publication of the law caused the delegation of authority, officers, facilities, and district infrastructure. The FMU manager perceives the impact, where the province takes over all the FMU areas in central Sulawesi. The provincial government is getting overwhelmed, especially in the financing of $21 \mathrm{FMU}$, its responsibility.

The provincial government of Central Sulawesi has established regional regulation No 8-year 2016 about the FMU management organization. The primary purpose of these rules' issuance is to clarify and streamline the FMU region's management through institutional redesigning activities. Of the total 21 areas of FMU, the merger subsequently conducted and formed 13 management organizations. Also, FMU financing is incorporated into the regional long-term management plan (RPJMD) in the 2016-2021 central Sulawesi province.

To increase access to the funding of the operationalization and management of FMU, the local government issued PERDA No. 44 in 2019 related to cooperation of forest utilization in the FMU region. Through this regulation, FMU gave the authority to develop the innovation of natural resource utilization through partnership cooperation. The development FMU chart has provided some improvement, including: (1) to assure the formal legal aspect of FMU; (2) ensure the support of the budgeting management of the FMU of the government.

Nonetheless, the main problem faced by the organization of the FMU in implementing the cast is overlapping the authority at the field level. The technical implementation Unit almost entirely manages authorization in the forest area (UPT) Ministry of Environment and Forestry (KLHK). Meanwhile, FMU is a regional device (Figure 3). In the end, the role of FMU at the field level is increasingly uncertain and impacts the forest management plan that has been compiled. Some sitelevel management activities within the FMU management area are conducted by one of the UPT KLHK without partnering with FMU.

The basic concept of the establishment of FMU is to create an institutional-based forest in the tread level, which will conduct a series of forest management activities, ranging from planning, structuring, and management. Its purpose is to improve forest sustainability, the welfare of the community, and create the independence of the FMU [25]. All forest areas are divided into FMU, which is part of strengthening the forest management system. However, these tasks and functions have not been optimally running at the field level. The problem of improper and delegation authority is a profound impact on the performance of the FMU in the field.

Funding from the central government does not flow into the FMU but directly to the technical Implementation Unit of the Central government (BPSKL, BPDAS-HL, BPHP, BPKH, KARHUTLA, and GAKUM [26-30]. The KLHK [31-33] dominates all forest arrangement and management activities. The situation causes FMU to perform more management activities on the non-state forest area (APL). But, in the outside of the forest area is still also found management activity by UPT KLHK, namely BPDAS-HL. That means the KLHK arrangement dominates all forest areas (inside and outside).

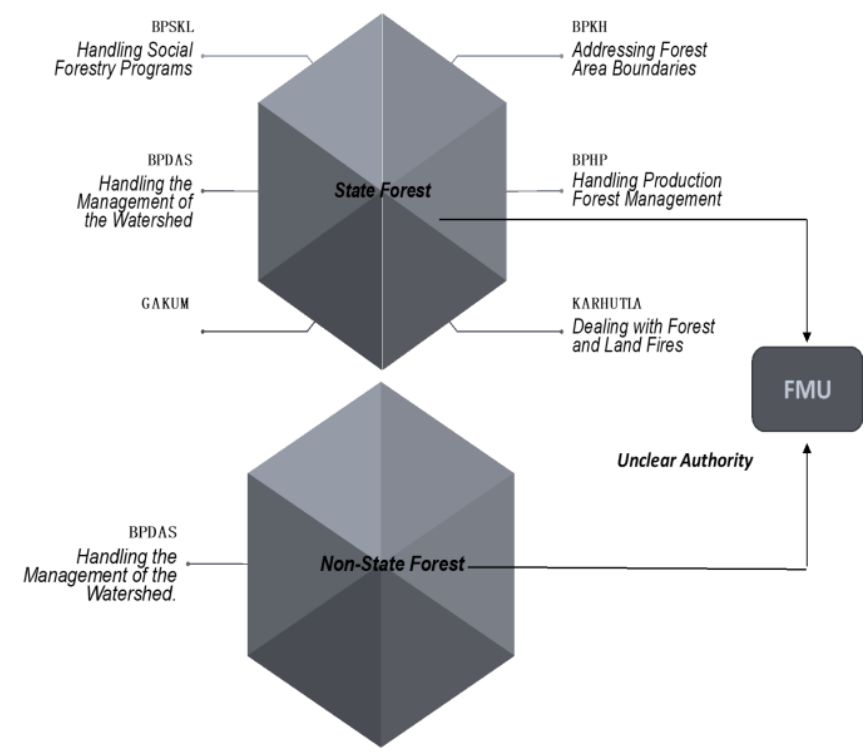

Figure 3. Overlapping authority on forest and non-forest area management

\subsection{The potential forest conflict area}

The FMU region generally faced a tenurial conflict problem, both within the access to the forest utilization. There is some evidence that community activity within the forest area existed before the formation of the FMU, being the reason for the community to do forest utilizing. In some locations, it was 
found that the activity conducted by the people in the forest area was a hereditary activity performed by their predecessors [34-37]. The form of utilization is quite diverse with varying intensity (Table 2). That shows the type of land-use systems related to public and corporate activities. The utilization is farmland, settlement, oil palm, gold mining, and land cultivations. The orientations in demand are for the family economy, the resettlement, the sustainability of family life, and the business orientation. Its utilization was varied from 1970 to the present.

The farmland dominates utilization in forest areas on the agroforestry types, which has been there for a long time. They planted crops and were under the trees that remained on the land. There is also some newly opened forest land but unused. The overall utilization of land found generally has livelihood and economics oriented.

Some previous studies report that land use in forest areas, especially those adjacent to community settlements, is farmland, processed, and livelihood, also used as an economicoriented business land. The situation continued for a long time, even before the forest area was claimed as an FMU [12, 19, $35]$.

\subsection{The trigger factors for tenurial conflict}

The dominant factor of conflict triggers is the difference of interest in the strategical value of the land. This dominant factor became the power driver, such as land-use conflicts, forest clearing, and gold-mining exploitation in forest areas. This condition is going to trigger physical conflicts when not resolved as soon as possible.

The situation reinforced with several factors related to the existence of FMU, namely: (a) the boundary of the FMU region that is difficult to recognize in the field; (b) the function of the FMU not yet felt its benefits evenly; (c) Information related to the policy/rules of land utilization in the forest area is not known by most of the community; (d) the role of extension of FMU is not running, and (e) activities related to prevention and handling of tenurial conflicts are still incidental

Some key informant in the field explains that the boundary of the forest-managed FMU is complicated to recognize in the field. This situation causes it challenging to distinguish between forest areas and non-forest areas. This uncertainty situation triggers a potential conflict of regional utilization in the FMU region. Theoretically, the problems faced by The FMU often come into contact with the three components of the institutional identifier, which is the jurisdiction boundary, which means the clarity of the limits of FMU or authority boundaries. Transparency of the FMU jurisdiction border can increase the managing forest area [36].

The role function of FMU is always attributed to the extent that FMU is capable of providing easy access to the region and forest resources, both to the public and the permit holders. Forest utilization by FMU efforts includes timber forest products from natural forests, plantation, natural tourism, environmental services, and non-timber forest product (palm sugar utilization, rattan, and Honey Bees). The province government has prepared several laws, namely PERDA, as a legal paying for its implementation. The other thing is the low resistance to the law of FMU, permit holders, and the public. Not to understand the rules but rather help in decision-making when facing operational problems related to decisions and issues involving the community individually or in institutional $[9,31]$.

Table 2. Land use activities within the forest areas of the FMU

\begin{tabular}{|c|c|c|c|c|}
\hline No & FMU & Land Use System & Since (year) & The Reasons \\
\hline \multirow[t]{5}{*}{1} & Pogogul & Farmland & 2005 & Economic needs \\
\hline & & Gold mining & Undefined & Business-oriented \\
\hline & & Gold mining & Undefined & Business-oriented \\
\hline & & Gold mining & Undefined & Business-oriented \\
\hline & & Gold mining & Undefined & Business-oriented \\
\hline \multirow[t]{8}{*}{2} & Dampelas Tinombo & Farmland; Settlement & 1980 & Livelihood \\
\hline & & Farmland; Settlement & 1990 & Doesn't have land \\
\hline & & Farmland; Settlement & 2000 & Doesn't have land \\
\hline & & Farmland; Settlement & 1970 & Development of definitive villages \\
\hline & & Farmland; Settlement & Undefined & Laudje (customary people) \\
\hline & & Farmland & Undefined & Economic-needs \\
\hline & & Farmland & Undefined & Economic-needs \\
\hline & & Farmland & Undefined & Economic-needs \\
\hline \multirow[t]{3}{*}{3} & Kulawi & Farmland & Undefined & Economic-needs \\
\hline & & Farmland & Undefined & Economic-needs \\
\hline & & Farmland; Settlement & Undefined & Livelihood \\
\hline \multirow[t]{11}{*}{4} & Sintuwu Maroso & land cultivation & 2001 & Livelihood and economic \\
\hline & & Farmland & 2005 & Livelihood and economic \\
\hline & & Farmland & 2001 & Livelihood and economic \\
\hline & & Farmland & 2004 & Livelihood and economic \\
\hline & & Farmland & 2000 & Livelihood and economic \\
\hline & & Farmland & 2000 & Livelihood and economic \\
\hline & & Farmland & 2000 & Livelihood and economic \\
\hline & & Farmland & 2000 & Livelihood and economic \\
\hline & & Farmland & 1980 & Livelihood and economic \\
\hline & & Farmland & 2012 & Livelihood and economic \\
\hline & & Farmland & 2012 & Livelihood and economic \\
\hline \multirow[t]{5}{*}{5} & Toili Baturube & Farmland & 2015 & Economic-needs \\
\hline & & Farmland & 1999 & Economic-needs \\
\hline & & Oil Palm & 1999 & Economic-needs \\
\hline & & Oil Palm & 1999 & Economic-needs \\
\hline & & Oil Palm & 2000 & Economic-needs \\
\hline
\end{tabular}


The implications of lack of understanding policies and rules are "the weak enforcement of policy in the field." These constraints are often found at the resort level, where FMU officers in the field often constrain implementing the latest relevant rules. Sometimes, that has been out of its newest state; officers are still implementing the old regulations. The rules' dynamics are very fast, while the information at the level of field-related standards is slowly acceptable.

Another thing that affects the FMU performance is the field extension officer's weakness in the field. Forestry extension is the spearhead of the FMU in socializing and synergized the FMU programs at the field level. Through the role of attachment, the internalization of FMU programs, especially those related directly to communities around forest areas, can be realized. Factual conditions in the field, current FMU no longer has field extension personnel.

The study showed that the weakness of functions and the role of extension workers or escorts in the area would lead to neglected community empowerment and weakening of the institutional community. This finding aligns with the study [37] that weak charge and institutional community will encourage increased forest damage, especially within the country's forest areas.

\subsection{The role of FMU in the improving public access}

It is related to the earlier that in the Covid-19 era, pressure on the forest area increased. Although quantitative has not been proven, the fact of the field indicates the pressure on forest areas. At several FMU in Central Sulawesi, encountered some activities of using illegal forest areas and potentially against forest damage (Figure 4).

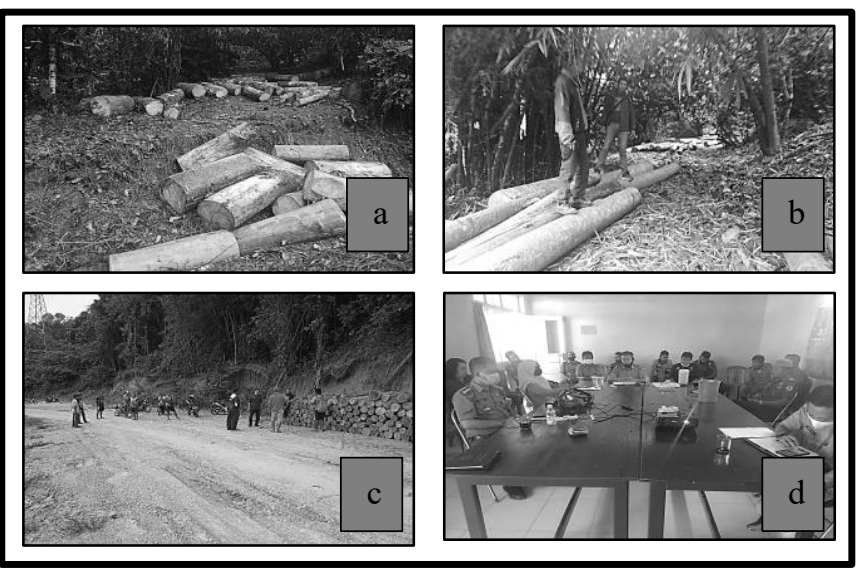

Figure 4. (a) and (b) The findings of timber log from illegal activity; (c) The timber log that prepares to move from forest area by someone; (d) The FMU coordination meeting for handling illicit utilization timber (Sources: The FMU of Sintuwu Maroso 2020)

The identification results conducted by the FMU, generally, the timber is taken from the forest area. Logging actors are people living around the forest, backed by timber buyers. Usually, the person gives an initial capital to the community to cut down the tree. The results of the acquired sold on timber traders who have given them. Their main reason for cutting trees into the region is the family economies. Also, they reveal that FMU is valued as less active in community engagement to circumcise and utilize forest areas.

The anticipating FMU made various efforts: increasing the intensity of supervision and monitoring forest areas and carrying out a series of special programs by optimizing nontimber forest product and environmental services: ecotourism, bird watching location, camping ground, mangrove tourism, and others. In its implementation and obtaining funding support from the region, they also get funding assistance through the partnership and utilization of Corporate Social Responsibility (CSR) funds from government-owned and private enterprises and grant aid from foreign countries.

The governor can cooperate with other regions and third parties to collaborate with other areas to strengthen forest precautions and support forest management. A corporation with third parties is carried out through forest utilization activities. Forest utilization cooperation is conducted in government affairs that become the regional authority for community welfare and the acceleration of public services. Some forms of potential partnerships to increase public access can see in Figure 5.

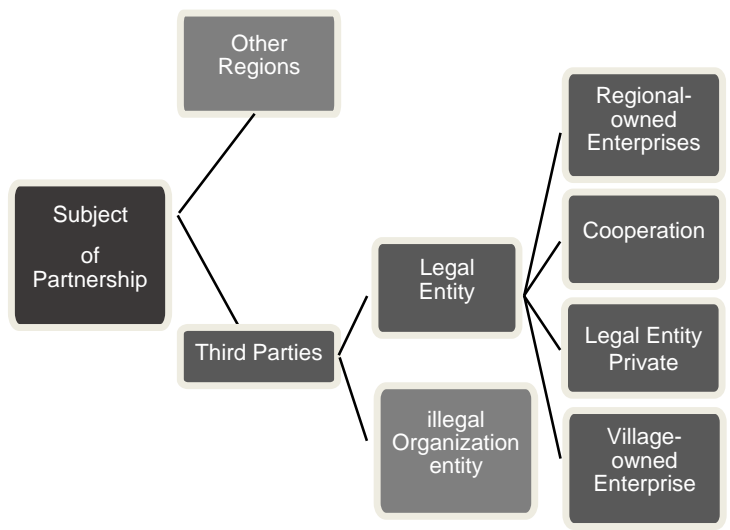

Figure 5. Forest management cooperation scheme

The head of province forestry service through the head of the FMU as a forest manager; and a third party cooperative partner: BUMD; cooperative; BUMS; BUMDes; and Mass Organization, who have activities and objectives to participate in forestry development. Some of the realized FMU cooperation is presented in Table 3.

Table 3. Cooperation of FMU with third parties and types of commodities developed

\begin{tabular}{|c|c|c|c|}
\hline No & FMU & Third Parties & Commodity \\
\hline 1 & Pogogul & $\begin{array}{l}\text { 1. UD. Permata } \\
\text { Ceria }\end{array}$ & Rattan \\
\hline 2 & $\begin{array}{c}\text { Dampelas } \\
\text { Tinombo }\end{array}$ & 1. UD. Margalewa & Rattan \\
\hline 3 & Kulawi & $\begin{array}{l}\text { 1. UD. Cahaya } \\
\text { Rejeki }\end{array}$ & Resin \\
\hline \multirow{7}{*}{4} & \multirow{7}{*}{$\begin{array}{l}\text { Sintuwu } \\
\text { Maroso }\end{array}$} & $\begin{array}{l}\text { 2. CV. Hijau } \\
\text { Potensi }\end{array}$ & Rattan \\
\hline & & $\begin{array}{c}\text { 3. CV. Rimba } \\
\text { Sulawesi Rotan Sigi }\end{array}$ & Rattan \\
\hline & & $\begin{array}{l}\text { 4. PT. Hong Thai } \\
\text { International }\end{array}$ & Pine sap \\
\hline & & 1. UD. Tawakkal & Rattan \\
\hline & & $\begin{array}{l}\text { 2. UD. Cahaya } \\
\text { Rejeki }\end{array}$ & Kopal Resin \\
\hline & & $\begin{array}{l}\text { 3. UD. Bright City } \\
\text { Internasional }\end{array}$ & Kopal Resin \\
\hline & & $\begin{array}{l}\text { 4. UD. Margalewa } \\
\text { Rotan }\end{array}$ & Rattan \\
\hline
\end{tabular}




\begin{tabular}{|c|c|c|c|}
\hline No & FMU & Third Parties & Commodity \\
\hline & & 5. UD. Sumber Baru & Rattan \\
\hline & & 6. UD. Sumber Baru & Kopal Resin \\
\hline & & 7. UD. Sumber Baru & Natural \\
\hline & & 8. UD. Bima Jaya & \\
\hline & & Perkasa & Kopal Resin \\
\hline & & 9. UD. Bima Jaya & Natural \\
\hline & & Perkasa & Honey \\
\hline & & 10. PT. Hong Thai & Pine sap \\
\hline & & $\begin{array}{l}\text { International } \\
\text { 11. Koperasi }\end{array}$ & \\
\hline & & Kalvari & Pine sap \\
\hline & & $\begin{array}{l}\text { 12. UD. Sejahtera } \\
\text { Bersama }\end{array}$ & Ecotourism \\
\hline \multirow[t]{2}{*}{5} & \multirow[t]{2}{*}{$\begin{array}{c}\text { Toili } \\
\text { Baturube }\end{array}$} & $\begin{array}{l}\text { 1. KTH. Pesona } \\
\text { Mangrove } \\
\text { Pandanwangi }\end{array}$ & Ecotourism \\
\hline & & 2. UD. Putri Jaya & Rattan \\
\hline
\end{tabular}

Meanwhile, forests can be land utilization, ecological services, timber, and non-timber forest products. Community involvement should adapt to the subject of cooperation and the forest land object to be accessed. Therefore, the active role of the FMU in preparing and recommending community involvement in much-needed partnership activities.

\section{CONCLUSION}

Community access in forest resource utilization is a deciding factor in helping the community face the economic crisis's impact. To achieve this, the role of FMU is necessary. As a management unit with the primary task and function of organizing forest governance in its region, including monitoring and assessing the implementation of forest management activities.

Also, FMU should open an investment opportunity to support forest management objectives, to improve community welfare. It can realize Increasing public access to forest states by providing forest management investment opportunities based on the community through a social forestry program and partnership scheme. It can have a broad impact and is in line with national issues on empowering forest communities. Therefore, the independence of FMU and the higher capacity is a necessary condition to make it happen.

\section{ACKNOWLEDGMENT}

We express our thanks to the Ministry of Education of the Republic of Indonesia and the Tadulako University Research Institute for all the facilities provided, that is we can carry out well.

\section{REFERENCES}

[1] Salghuna, N.N., Prasad, R.C.P., Asha Kumari, J. (2018). Assessing the impact of land use and land cover changes on the remnant patches of Kondapalli reserve forest of the Eastern Ghats, Andhra Pradesh, India. The Egyptian Journal of Remote Sensing and Space Science, 21(3): 419-429. https://doi.org/10.1016/j.ejrs.2018.01.005

[2] Trædal, L.T., Vedeld, P. (2018). Cultivating forests: The role of forest land in household livelihood adaptive strategies in the Bac Kan Province of northern Vietnam. Land Use Policy, 73: 249-258. https://doi.org/10.1016/j.landusepol.2018.02.004

[3] van Haren, N., Fleiner, R., Liniger, H., Harari, N. (2019). Contribution of community-based initiatives to the sustainable development goal of Land Degradation Neutrality. Environmental Science \& Policy, 94: 211219. https://doi.org/10.1016/j.envsci.2018.12.017

[4] Irawan, A., Mairi, K., Ekawati, S. (2016). Analysis of tenurial conflict in production forest management unit (Pfmu) Model Poigar. J. Wasian, 3(2): 79. https://doi.org/10.20886/jwas.v3i2.1595

[5] Luo, Y., Liu, J., Zhang, D., Dong, J. (2015). Actor, customary regulation and case study of collective forest tenure reform intervention in China. Small-scale Forestry, 14(2): 155-169. https://doi.org/10.1007/ s11842-0149279-1

[6] Yin, R., Zulu, L., Qi, J., Freudenberger, M., Sommerville, M. (2016). Empirical linkages between devolved tenure systems and forest conditions: Challenges, findings, and recommendations. Forest Policy and Economics, 73: 294-299. https://doi.org/10.1016/j.forpol.2016.05.008

[7] Resosudarmo, I.A.P., Tacconi, L., Sloan, S., Hamdani, F.A.U., Subarudi, Alviya, I., Muttaqin, M.Z. (2019). Indonesia's land reform: Implications for local livelihoods and climate change. Forest Policy and Economics, 108: 101903. https://doi.org/10.1016/j.forpol.2019.04.007

[8] Duguma, L.A., Atela, J., Negassa Ayana, A., Alemagi, D., Mpanda, M., Nyago, M., Minang, P., Nzyoka, J., Foundjem-Tita, D., Ndjebet, C. (2018). Community forestry frameworks in sub-Saharan Africa and the impact on sustainable development. E\&S, 23(4): 21. https://doi.org/10.5751/ES-10514-230421

[9] Golar, G., Basir-Cyio, M., Isrun, I., Bakri, R., Rusydi, M., Bohari, B., Pratama, M.F. (2021). Recovery of agricultural areas affected by traditional gold mining: Sustainable food supply stability. International Journal of Design \& Nature and Ecodynamics, 16(2): 177-184. https://doi.org/10.18280/ijdne.160207

[10] Teucher, M., Schmitt, C.B., Wiese, A., Apfelbeck, B., Maghenda, M., Pellikka, P., Lens, L., Habel, J.C. (2020). Behind the fog: Forest degradation despite logging bans in an East African cloud forest. Global Ecology and Conservation, 22: e01024. https://doi.org/10.1016/j.gecco.2020.e01024

[11] Golar, G., Malik, A., Muis, H., Herman, A., Nurudin, N., Lukman, L. (2020). The social-economic impact of COVID-19 pandemic: Implications for potential forest degradation. Heliyon, 6(10): e05354. https://doi.org/10.1016/j.heliyon.2020.e05354

[12] Westin, K., Holm, E. (2018). Do trees make people more rooted? Private forest owners 'migration'. Forest Policy and Economics, 94: 11-20. https://doi.org/10.1016/j.forpol.2018.06.003

[13] Handoko, C., Yumantoko, Y. (2015). Local perspectives on tenure rights and conflict in Fmu Rinjani Barat, West Nusa Tenggara Province. Jurnal Penelitian Kehutanan Wallacea, $4(2)$ : 157. https://doi.org/10.18330/jwallacea.2015.vol4iss2pp157170

[14] Irawan, A., Mairi, K., Ekawati, S. (2016). Analysis of tenurial conflict in production forest management unit (Pfmu) Model Poigar. Jurnal Wasian, 3(2). 
https://doi.org/10.20886/jwas.v3i2.1595

[15] Riggs, R.A., Sayer, J., Margules, C., Boedhihartono, A.K., Langston, J.D., Sutanto, H. (2016). Forest tenure and conflict in Indonesia: Contested rights in Rempek Village, Lombok. Land Use Policy, 57: 241-249. https://doi.org/10.1016/j.landusepol.2016.06.002

[16] Bernard, T., Doss, C., Hidrobo, M., Hoel, J., Kieran, C. (2020). Ask me why: Patterns of intrahousehold decision-making. World Development, 125: 104671. https://doi.org/10.1016/j.worlddev.2019.104671

[17] Schürmann, A., Kleemann, J., Fürst, C., Teucher, M. (2020). Assessing the relationship between land tenure issues and land cover changes around the Arabuko Sokoke Forest in Kenya. Land Use Policy, 95: 104625. https://doi.org/10.1016/j.landusepol.2020.104625

[18] Mockrin, M.H., Locke, D.H., Stewart, S.I., Hammer, R.B., Radeloff, V.C. (2019). Forests, houses, or both? Relationships between land cover, housing characteristics, and resident socioeconomic status across ecoregions. Journal of Environmental Management, 234: 464-475. https://doi.org/10.1016/j.jenvman.2018.12.001

[19] Tsujino, R., Yumoto, T., Kitamura, S., Djamaluddin, I., Darnaedi, D. (2016). History of forest loss and degradation in Indonesia. Land Use Policy, 57: 335-347. https://doi.org/10.1016/j.landusepol.2016.05.034

[20] Okumu, B., Muchapondwa, E. (2020). Welfare and forest cover impacts of incentive based conservation: Evidence from Kenyan community forest associations. World Development, 129: 104890 https://doi.org/10.1016/j.worlddev.2020.104890

[21] Golar, G., Mahfudz, Malik, A., Muis, H. (2020). The adaptive-collaborative as a strategy comunications for conflict resolution on the National Park. Ecology, Environment and Conservation, 24(4): 1836-1843.

[22] Bergius, M., Benjaminsen, T.A., Maganga, F., Buhaug, H. (2020). Green economy, degradation narratives, and land-use conflicts in Tanzania. World Development, 129: 104850. https://doi.org/10.1016/j.worlddev.2019.104850

[23] Aguilar-Støen, M. (2018). Social forestry movements and science-policy networks: The politics of the forestry incentives program in Guatemala. Geoforum, 90: 20-26. https://doi.org/10.1016/j.geoforum.2018.01.014

[24] Surati, S., Sylviani, S. (2016). The role of the parties in handling conflict in the Mahakam delta production forest management unit, East Kalimantan. Journal of Forestry Policy Analysis, 13(3). https://doi.org/10.20886/jakk.2016.13.3.221-235

[25] Leijten, F., Sim, S., King, H., Verburg, P.H. (2021). Local deforestation spillovers induced by forest moratoria: Evidence from Indonesia. Land Use Policy, 109: 105690 https://doi.org/10.1016/j.landusepol.2021.105690

[26] van der Maesen, L., Cadman, T. (2015). Sustainable forest management: The role of government agencies, NGOs, and local communities in Western Australia. The International Journal of Social Quality, 5(2). https://doi.org/10.3167/IJSQ.2015.050204
[27] Sahide, M.A.K., Maryudi, A., Supratman, S., Giessen, L. (2016). Is Indonesia utilising its international partners? The driving forces behind Forest Management Units. Forest Policy and Economics, 69: 11-20. https://doi.org/10.1016/j.forpol.2016.04.002

[28] Bluffstone, R.A., Somanathan, E., Jha, P., Luintel, H., Bista, R., Toman, M., Paudel, N., Adhikari, B. (2018). Does collective action sequester carbon? Evidence from the Nepal community forestry program. World Development, 101: 133-141. https://doi.org/10.1016/j.worlddev.2017.07.030

[29] Lee, G., Suzuki, A. (2020). Motivation for information exchange in a virtual community of practice: Evidence from a Facebook group for shrimp farmers. World Development, 125 : 104698. https://doi.org/10.1016/j.worlddev.2019.104698

[30] Muttaqin, M.Z., Alviya, I., Lugina, M., Hamdani, F.A.U. Indartik. (2019). Developing community-based forest ecosystem service management to reduce emissions from deforestation and forest degradation. Forest Policy and Economics, 108: 101938. https://doi.org/10.1016/j.forpol.2019.05.024

[31] García-López, G., Antinori, C. (2018). Between grassroots collective action and state mandates: The hybridity of multi-level forest associations in Mexico. Conservation and Society, 16(2): 193-204. https://doi.org/10.4103/cs.cs_16_115

[32] Khalwani, K.M. (2008). Perception and motivation of local people towards the people's forest program GNRHL (Cases in Cigudeg Village, Cigudeg Subdistrict and Tamansari Village, Tamansari Subdistrict, Bogor Regency). p. 94.

[33] Macqueen, D., Bolin, A., Greijmans, M., Grouwels, S., Humphries, S. (2020). Innovations towards prosperity emerging in locally controlled forest business models and prospects for scaling up. World Development, 125: 104382. https://doi.org/10.1016/j.worlddev.2018.08.004

[34] Sahide, M.A.K., Fisher, M.R., Maryudi, A., Wong, G.Y., Supratman, S., Alam, S. (2019). The bureaucratic politics of conservation in governing land conflict: A typology of capacities. MethodsX, 6: 2536-2543. https://doi.org/10.1016/j.mex.2019.10.022

[35] Golar, G., Cyio, M.B., Rusydi, M., Bakri, R. (2019). Gold mining and its impact on agricultural land, public health, violation of the law: A study on Poboya traditional mining, Palu, Indonesia. Int. Jour. of Publ. Health Rese. \& Develop., 10(10): 924. https://doi.org/10.5958/0976-5506.2019.02939.5

[36] Faye, P. (2018). Theorising derecognition of local government authorities as political injustice: The effects of technical claims in Senegal's forestry. Conservation \& Society, 15(4): 414-25. https://doi.org/10.4103/cs.cs 1699

[37] Massiri, S.D., Nugroho, B., Kartodihardjo, H., Soekmadi, R. (2019). Institutional sustainability of a community conservation agreement in Lore Lindu National Park. FS, 3(1). https://doi.org/10.24259/fs.v3i1. 5204 